\title{
Declines in mRNA Expression of Different Subunits May Account for Differential Effects of Aging on Agonist and Antagonist Binding to the NMDA Receptor
}

\author{
Kathy R. Magnusson \\ Department of Anatomy and Neurobiology, College of Veterinary Medicine and Biomedical Sciences, Colorado State \\ University, Fort Collins, Colorado 80523-1670
}

\begin{abstract}
The purpose of the present study was to determine whether some of the age-related changes that occur in binding to the NMDA receptor complex can be accounted for by changes in subunit expression during the aging process. In situ hybridization for the NMDA subunits $\zeta 1, \epsilon 1$, and $\epsilon 2$, and receptor autoradiography, using the agonist glutamate and the competitive antagonist [( \pm )-2-carboxypiperazin-4-yl] propyl-1-phosphonic acid (CPP), were performed on sections from C57BI/6 mice representing three different age groups $(3,10$, and 30 months of age). There was a significant overall decrease between 3 and 30 month olds in the density of mRNA for the $\zeta 1$ subunit in the cortex and hippocampus, but only a few individual brain regions exhibited significant declines. The mRNA for the $\epsilon 2$ subunit was significantly decreased in a majority of cortical regions
\end{abstract}

Memory declines are the earliest cognitive dysfunctions to be detected during the aging process (Albert and Funkenstein, 1992). Age-related deficits in memory performance are seen in humans and nonhuman primates (Gallagher and Nicolle, 1993; Gallagher and Rapp, 1997), dogs (Head et al., 1995), and rodents (Gage et al., 1984; Rapp et al., 1987; Barnes, 1988; Pelleymounter et al., 1990). The NMDA receptor, a subtype of glutamate receptor, is important in learning and memory functions (Cotman et al., 1989; Magnusson, 1998b). Antagonists of the NMDA receptor block the initiation of long-term potentiation in the hippocampus (Harris et al., 1984; Morris et al., 1986; Bashir et al., 1991) and neocortex (Artola and Singer, 1994) and interfere with performance of learning and memory tasks (Alessandri et al., 1989; Mondadori et al., 1989; Heale and Harley, 1990; Morris and Davis, 1994).

Aging animals exhibit declines in NMDA receptor binding densities and functions. NMDA-stimulated release of transmitters is decreased with increasing age (Gonzales et al., 1991; Pittaluga et al., 1993). Long-term potentiation is also negatively altered in aged rodents (Barnes and McNaughton, 1985; Deupree et al., 1993). Age-related declines in binding of glutamate and

Received Aug. 23, 1999; revised Dec. 7, 1999; accepted Dec. 10, 1999.

This research was supported by a First Independent Research Support and Transition Award AG10607 (K.R.M.) and Research Career Development Award AG00659 (K.R.M.). I acknowledge Dr. Scott Nelson for technical advice on the project and Ginger Sammonds, Sarah Zimmerman, and Tara Hogan for their technical assistance.

Correspondence should be addressed to Dr. Kathy Magnusson, Department of Anatomy and Neurobiology, College of Veterinary Medicine and Biomedical Sciences, Colorado State University, Fort Collins, CO 80523-1670. E-mail: kmagnuss@lamar.colostate.edu.

Copyright (C) 2000 Society for Neuroscience $\quad 0270-6474 / 00 / 201666-09 \$ 15.00 / 0$ and in the dentate granule cells. Emulsion analysis indicated that the change in the density of $\epsilon 2$ subunit mRNA in the inner frontal cortex was primarily attributable to a decrease in the amount of messages per cell. Age-related changes in mRNA density of the $\epsilon 2$ subunit correlated with changes in NMDAdisplaceable $\left[{ }^{3} \mathrm{H}\right]$ glutamate binding, and mRNA density changes in the $\zeta 1$ subunit showed a significant relationship with changes in $\left[{ }^{3} \mathrm{H}\right] \mathrm{CPP}$ binding in the 30 -month-old mice. These results suggest that changes during aging in the expression of different subunits of the NMDA receptor may account for the differential effects of aging on agonist versus antagonist binding to the NMDA binding site.

Key words: NMDA receptors; NMDA subunits; in situ hybridization; glutamate; aging; $m R N A$

[( \pm )-2-carboxypiperazin-4-yl] propyl-1-phosphonic acid (CPP) to NMDA binding sites are seen in mice, rats, and monkeys (Kito et al., 1990; Pelleymounter et al., 1990; Tamaru et al., 1991; Wenk et al., 1991; Magnusson, 1995). Humans also exhibit declines with increased age in binding of $\left[{ }^{3} \mathrm{H}\right] \mathrm{MK} 801$ to the NMDA receptor in the frontal cortex (Piggott et al., 1992). Changes in NMDA binding sites during aging in both frontal cortical regions (Magnusson, 1998a) and in the hippocampus (Pelleymounter et al., 1990; Magnusson, 1998a) have been correlated with poor performance in reference memory tasks.

The effects of aging on the different binding sites of the NMDA receptor complex are not homogeneous (Magnusson, 1995). In addition, differences occur between antagonist and agonist binding to the NMDA binding site; $\left[{ }^{3} \mathrm{H}\right] \mathrm{CPP}$ binding densities decline similarly during aging to NMDA-displaceable $\left[{ }^{3} \mathrm{H}\right]$ glutamate binding in the cerebral cortex of mice (Magnusson, 1995), but differ in the degree of change in the hippocampus (Pelleymounter et al., 1990; Magnusson, 1995; Nicolle et al., 1996). The mechanisms that are responsible for these heterogeneous effects are not known.

Functional subunits of the NMDA receptor complex have been cloned for mice (Ikeda et al., 1992; Kutsuwada et al., 1992; Meguro et al., 1992; Yamazaki et al., 1992). The $\zeta 1$ (rat NR1) subunit has the same distribution as NMDA-displaceable $\left[{ }^{3} \mathrm{H}\right]$ glutamate binding (Moriyoshi et al., 1991; Meguro et al., 1992; Nakanishi, 1992). There are four members of the $\epsilon$ family of subunits, $\epsilon 1-4$ (rat NR2A-D), in the mouse (Ikeda et al., 1992; Kutsuwada et al., 1992; Meguro et al., 1992). These subtypes confer different agonist-antagonist affinities to $\zeta 1 / \epsilon$ heteromeric receptors (Kutsuwada et al., 1992; Yamazaki et al., 1992).

The purpose of the present study was to determine whether 

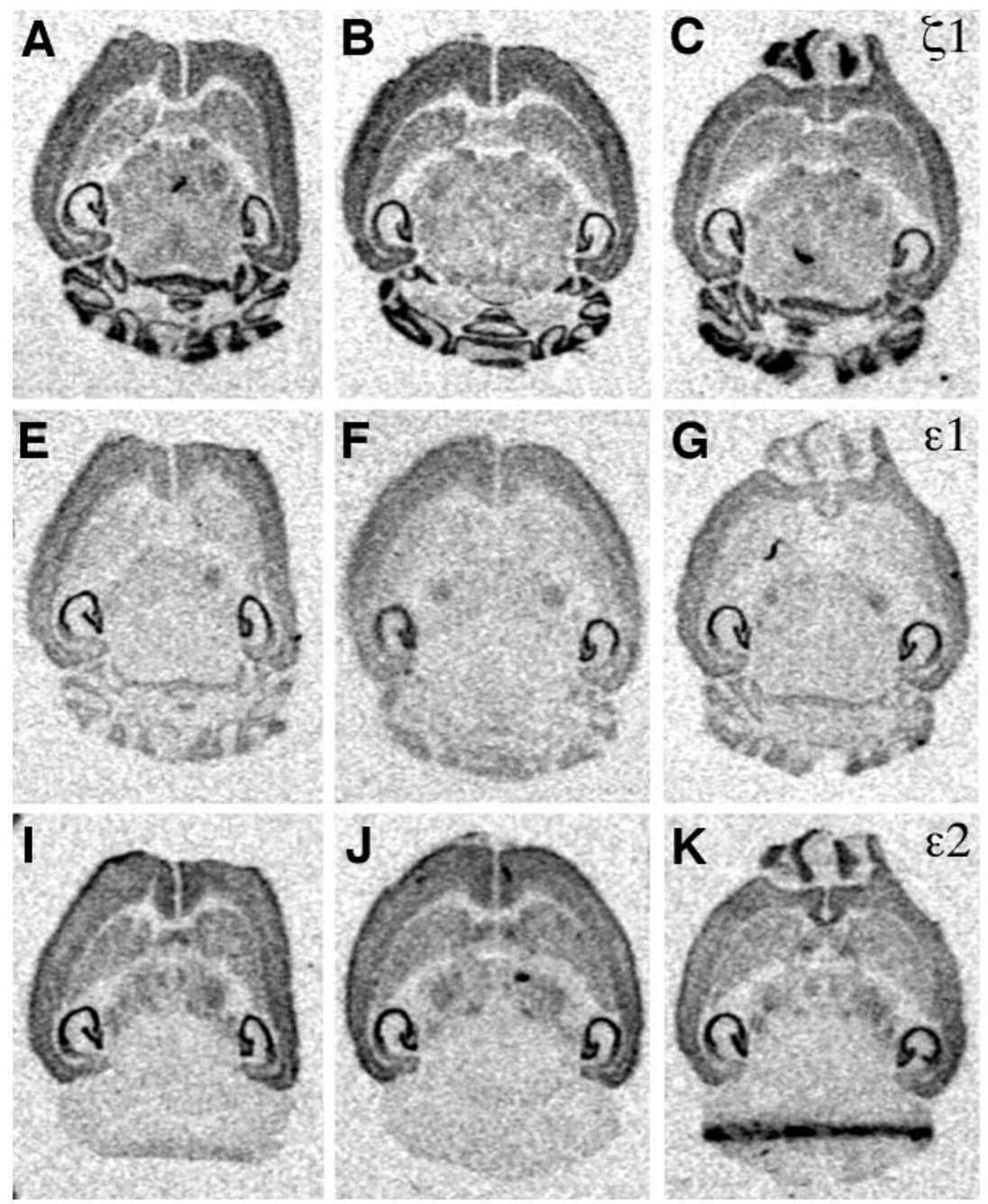

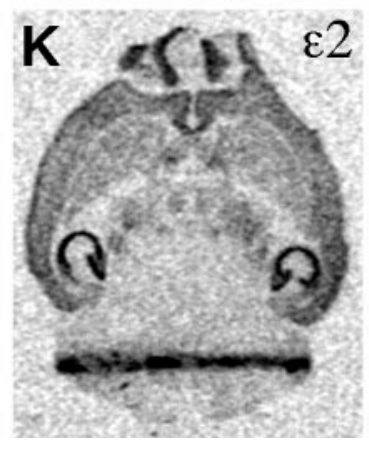

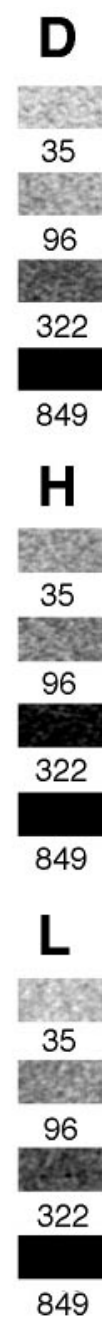

Figure 1. In situ hybridization for NMDA subunits in different ages of mice. Film autoradiograms of the hybridized mRNA for $\zeta 1(A-$ $C), \epsilon 1(E-G)$, and $\epsilon 2(I-K)$ subunit of the NMDA receptor in $3(A, E, I)-, 10(B, F, J)$-, and $30(C, G, K)$-month-old mice. $D, H, L$, Densities (counts per minute per milligram of tissue) of binding for different gray levels for the $\zeta 1$ probe in $A-C(D), \epsilon 1$ probe in $E-G(H)$, and $\epsilon 2$ probe in $I-K(L)$. some of the age-related changes that occur in binding to the NMDA receptor complex can be accounted for by changes in subunit expression during the aging process.

\section{MATERIALS AND METHODS}

\section{Animals}

Thirty-six male C57Bl/6 mice (National Institute on Aging, Bethesda, MD) representing three different age groups (3, 10, and 30 months of age) were fed ad libitum and housed under $12 \mathrm{hr}$ light/dark conditions for 3-7 d before killing. The mice were killed by exposure to $\mathrm{CO}_{2}$, followed by decapitation. The brains were removed, frozen on dry ice, and stored in a $-70^{\circ} \mathrm{C}$ freezer. Twenty micrometer horizontal sections were cut from the brain with a Zeiss Microm 500 cryostat and placed on gelcoated slides, which were stored at $-70^{\circ} \mathrm{C}$ until used. Sections from two different members of each age group were present on each slide, and the order of placement on the slide was varied between cutting groups.

\section{In situ hybridization}

Oligonucleotides (45 bases) were commercially prepared (Macromolecular Resources, Colorado State University) for the $\zeta 1$ (complimentary to nucleotide residues -54 to -10$), \epsilon 1$ (2901-2945), and $\epsilon 2$ (3107-3151) subunits of the mouse NMDA receptor (Watanabe et al., 1992, 1993) and were labeled with ${ }^{33} \mathrm{P}$-dATP using terminal deoxyribonucleotidyl transferase (New England Nuclear, Boston, MA) and NENSORB20 purification cartridges (New England Nuclear). In situ hybridization was performed according to the method of Watanabe et al. $(1992,1993)$. Each solution step was performed with gentle rotation on a rotating table except for the fixation and hybridization steps. Slides with sections were thawed, air-dried, fixed in $4 \%$ paraformaldehyde-PBS, $\mathrm{pH} 7.2\left(25^{\circ} \mathrm{C}\right)$ for $15 \mathrm{~min}$, placed in $2 \mathrm{mg} / \mathrm{ml}$ glycine in $\mathrm{PBS}, \mathrm{pH} 7.2\left(25^{\circ} \mathrm{C}\right)$ for $20 \mathrm{~min}$, and placed in $0.25 \%$ acetic anhydride $-0.1 \mathrm{M}$ triethanolamine, $\mathrm{pH} 8.0\left(25^{\circ} \mathrm{C}\right)$ for $10 \mathrm{~min}$. Slides were placed in coplin jars for $2 \mathrm{hr}$ in a prehybridization solution that consisted of $50 \%$ formamide, $0.1 \mathrm{M}$ Tris- $\mathrm{HCl}, \mathrm{pH} 7.5,4 \times$ SSC $(1 \times \mathrm{SSC}=150 \mathrm{~mm} \mathrm{NaCl}$ and $15 \mathrm{~mm}$ sodium citrate), $0.02 \%$ Ficoll, $0.02 \%$ polyvinylpyrrolidone, $0.02 \%$ bovine serum albumin, $2 \%$ sarkosyl, and $250 \mu \mathrm{g} / \mathrm{ml}$ salmon testes DNA. Chemicals were purchased from Sigma (St. Louis, MO). Slides were then successively washed for $5 \mathrm{~min}$ each in $2 \times$ SSC, 70 and $100 \%$ ethanol, and air-dried for $15 \mathrm{~min}$. Hybridization was performed by placing $100 \mu \mathrm{l}$ of prehybridization solution with $10 \%$ dextran sulfate and $1 \times 10^{6} \mathrm{dpm}$ of ${ }^{33} \mathrm{P}$-labeled oligonucleotide probe added onto the slides, coverslipping the slides with parafilm, and incubating them for $18 \mathrm{hr}$ in a $42^{\circ} \mathrm{C}$ oven humidified with $5 \times$ SSC. Coverslips were removed, and slides were rinsed for $40 \mathrm{~min}$ each in $2 \times$ SSC and $0.1 \%$ sarkosyl $\left(25^{\circ} \mathrm{C}\right)$ and twice in $0.1 \times$ SSC and $0.1 \%$ sarkosyl $\left(55^{\circ} \mathrm{C}\right)$ and air-dried. Nonspecific binding was determined by addition of 20 -fold excess cold oligo to the hybridization solution on some slides. Sections were exposed to Hyperfilm- $\beta$ max (Amersham, Piscataway, NJ) for 3-5 d along with brain paste standards. The standards were prepared by homogenizing whole brain from 12 3-month-old mice and mixing in measured amounts of ${ }^{33} \mathrm{P}$-dATP (Marks et al., 1992). The actual concentrations were determined by scintillation counting of weighed aliquots and ranged from 95,000 to $14 \mathrm{cpm} / \mathrm{mg}$ wet weight of brain tissue. Brain and standard images were captured using a Macintosh IIci computer with a Quickcapture board, a Panasonic CCD camera, and NIH Image software. Quantitative densitometry was performed on the images from four sections for total binding and two sections for nonspecific binding from each animal with the use of NIH Image software. The standards were used to convert optical density to counts per minute per milligram of tissue. Specific signal was determined by subtracting nonspecific binding from total binding. Slides were then dipped in photographic emulsion (NTB2; Eastman Kodak, Rochester, NY), exposed for 

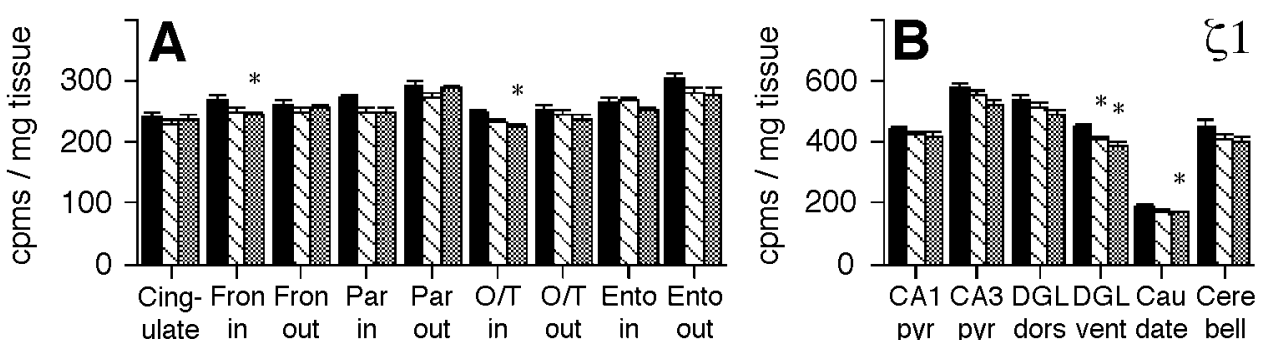

pyr pyr dors vent date bell
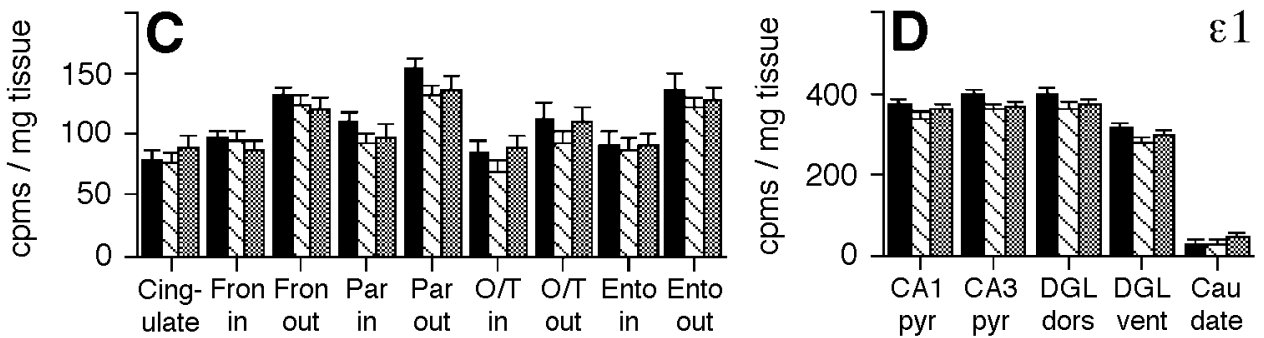

2. Quantitative comparison of mRNA densities for NMDA subunits within brain regions of different ages of mice. Densities (counts per minute per milligram of tissue) of mRNA for the $\zeta 1(A$, $B), \epsilon 1(C, D)$, and $\epsilon 2(E, F)$ subunits of the NMDA receptor in different cortical $(A, C$, $E)$ and hippocampal and subcortical $(B, D$, $F)$ regions in 3-, 10-, and 30-month-old mice. * indicates $p<0.05$ for difference from 3-month-old mice. \# indicates $p<$ 0.05 for difference from 10-month-old mice. $A-D, n=12$ for 3 and 10 month olds, $n=13$ for 30 month olds. $E, F, n=11$ for 3 month olds, 12 for 10 month olds, and 10 for 30 month olds. in, Cortical layers IV-VI; out, cortical layers II-III; Fron, frontal; Par, parietal; $O / T$, occipital/temporal; Ento, entorhinal; pyr, pyramidal cell layer; $D G L$, dentate granule cell layer; dors, dorsal blade; vent, ventral blade; Cerebell, cerebellum.
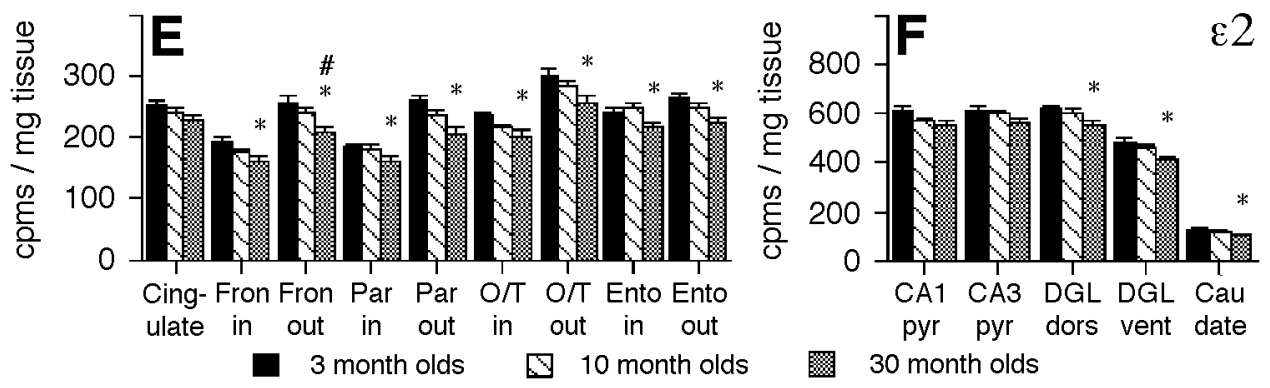

8-12 weeks, developed in D19 developer (Eastman Kodak), and counterstained with a Giemsa stain. Images of cells and grains within specific brain regions were captured on the computer as described above. Grain area was determined by filtering images to highlight grains (Smolen and Beaston-Wimmer, 1990), thresholding, and analyzing particles within 12 cells per slide for a total of 48 cells for total binding and 24 cells for nonspecific binding for each animal (Watanabe et al., 1993). An overall average for cells and for animals was calculated, and specific binding was determined as described for film analysis.

\section{Autoradiography}

NMDA binding sites. Binding was performed as previously described (Magnusson, 1995). Slides were preincubated in cold $\left(4^{\circ} \mathrm{C}\right) 50 \mathrm{~mm}$ Tris acetate (TA) buffer, $\mathrm{pH} 7.0$, for $30 \mathrm{~min}$, followed by $2 \times 10 \mathrm{~min}$ incubations in warm TA buffer, $\mathrm{pH} 7.0\left(30^{\circ} \mathrm{C}\right)$. Sections were then incubated in a solution of $100 \mathrm{nM}\left[{ }^{3} \mathrm{H}\right] \mathrm{L}$-glutamate (New England Nuclear), $1 \mu \mathrm{M}$ kainate, $5 \mu \mathrm{M}$ AMPA, and $100 \mu \mathrm{M}$ 4-acetamido-4'-isothiocyanotostilbene-2, $2^{\prime}$-disulfonic acid for $10 \mathrm{~min}$ at $4^{\circ} \mathrm{C}$. Slides were rinsed in four changes of TA buffer $\left(4^{\circ} \mathrm{C}\right)$ for a total of $30 \mathrm{sec}$ and dried by a stream of compressed air at room temperature. Unlabeled $200 \mu \mathrm{M}$ NMDA was added to the incubation solution for determining nonspecific binding.

$C P P$ binding sites. Binding was performed as previously described (Magnusson, 1995). Slides were preincubated in $50 \mathrm{~mm}$ TA buffer, $\mathrm{pH}$ 7.6, for $30 \mathrm{~min}$ at $4^{\circ} \mathrm{C}$, followed by $2 \times 10 \mathrm{~min}$ incubations in TA buffer at $30^{\circ} \mathrm{C}$. Tissue was incubated in a solution containing $100 \mathrm{~nm}\left[{ }^{3} \mathrm{H}\right] \mathrm{CPP}$ (New England Nuclear) for $20 \mathrm{~min}$ at $4^{\circ} \mathrm{C}$ for total binding. Nonspecific binding was determined by the addition of $100 \mu \mathrm{M}$ unlabeled CPP to the incubation solution. Slides were rinsed in four changes of TA buffer for $15 \mathrm{sec}$ at $4^{\circ} \mathrm{C}$ and dried by a stream of compressed air at room temperature.

Slides were allowed to dry overnight and were apposed to tritiumsensitive film (Amersham) along with tritium standards (Amersham) at $-20^{\circ} \mathrm{C}$ for $10 \mathrm{~d}$. Exposed films were developed in D-19 developer (Eastman Kodak). Brain images were captured and analyzed as described for in situ hybridization. Tritium standards were used to convert optical density measurements to femtomoles per milligram of protein for each brain region analyzed. Specific binding was determined by subtracting nonspecific binding from total binding.

Statistical analysis. Age-related differences in densities of mRNA and receptor binding were analyzed by ANOVA followed by Fisher's modified LSD using either SPSS or GB-Stat software. Examination of agerelated differences within brain regions was part of the original plan. Correlational analysis was done by examining the relationships between age-related changes in receptor binding and mRNA densities across multiple brain regions. Separate analyses were performed for 10- and 30-month-old mice. The receptor binding or mRNA density within each brain region in 10- and 30-month-old mice was expressed as a percentage of the average binding or mRNA density for 3 month olds within that brain region. The percentages for each animal within an age group were averaged to obtain a mean percentage of 3-month-old binding or mRNA density for that age group within each brain region. These means for receptor binding for individual brain regions were plotted against the respective percentage of 3-month-old mRNA densities within the same regions, and Pearson's correlation coefficients were obtained.

\section{RESULTS}

\section{$\zeta 1$ subunit mRNA}

There was a significant main effect of age, $F_{(2,34)}=4.29, p=$ 0.022 , and brain region, $F_{(14,476)}=637, p<0.001$, on density (counts per minute per milligram of tissue) of mRNA for the $\zeta 1$ subunit of the NMDA receptor (Fig. $2 A, B$ ). There was also a significant interaction between age and brain region, $F_{(28,476)}$ $=1.72, p=0.013$. Densities of mRNA for the $\zeta 1$ subunit were higher in the major cell layers of the hippocampus than in the subregions of the cortex in all ages of mice (Figs. $1 A-D, 2 A, B$ ). Within individual brain regions, the 30 month olds showed significant decreases from densities seen in 3-month-old mice in layers II-III of the frontal and occipital/temporal cortices, in the granule cells of the ventral blade of the dentate gyrus, and in the caudate nucleus (Fig. $2 A, B$ ). There was also a significant decrease in the density of the mRNA for the $\zeta 1$ subunit between 3 and 10 months of age in the ventral blade of the dentate gyrus granule cell layer (Fig. $2 A, B$ ). 


\section{$\epsilon 1$ subunit mRNA}

There was a significant main effect of brain region, $F_{(14,476)}=779$, $p<0.001$, on densities of mRNA for the $\epsilon 1$ subunit of the NMDA receptor. There was no significant main effect of age, $F_{(2,34)}=$ $0.83, p=0.44$, and no significant interaction between age and brain region, $F_{(28,476)}=1.15, p=0.27$ (Fig. $2 C, D$ ). Average densities were higher in the major cell layers of the hippocampus than in the layers of the cortex in all ages (Figs. $1 E-H, 2 C, D$ ). No brain regions showed significant changes during aging in the density of mRNA for the $\epsilon 1$ subunit (Fig. 2C,D).

\section{E2 subunit mRNA}

There was a significant main effect of age, $F_{(2,30)}=7.89, p=$ 0.002 , and brain region, $F_{(13,390)}=1275, p<0.001$, on densities of mRNA for the $\epsilon 2$ subunit of the NMDA receptor. There was no significant interaction between age and brain region, $F_{(26,390)}$ $=1.4, p=0.095$. Densities for $\epsilon 2 \mathrm{mRNA}$ were highest in the major cell layers of the hippocampus than in the cortex, and there was a higher density in layers II-III of the cortex than in the inner layers in all ages examined (Figs. $1 I-L, 2 E, F$ ). Within brain regions, the $\epsilon 2$ mRNA was significantly decreased between 3 and 30 months of age in all cortical regions, except the cingulate cortex, in the granule cell layer of the dentate gyrus, and in the caudate nucleus (Fig. 2E,F). Layers II-III of the frontal cortex also showed significant reductions in mRNA density between 10and 30-month-old mice (Figs. 1J,K, 2E).

\section{Emulsion analysis of mRNA for subunits of the NMDA receptor}

The average specific grain area per cell in different ages of mice was examined to determine whether the declines in mRNA density for the $\zeta 1$ and $\epsilon 2$ subunits of the NMDA receptor were attributable to a decrease in message per cell or a decrease in cell numbers with message density maintained within the remaining cells. We used average grain area per cell, as opposed to numbers of grains, to take into account that one or more messages in close proximity could have produced silver grains that coalesced into a single grain (Smolen and Beaston-Wimmer, 1990). A representative field, exhibiting cells from the inner layers (IV-VI) of the frontal cortex overlain with silver grains (black dots), is shown in Figure $3 A$. The analysis of the outer cortex included both layers II and III, but analysis of the inner layers was concentrated on the layer $\mathrm{V}$ pyramidal cells. There was a significant decrease in grain area per cell for $\epsilon 2$ mRNA between 3 and 30 months of age in the inner layers of the frontal cortex (Fig. $3 B$ ). Both $\epsilon 2$ and $\zeta 1$ mRNA exhibited significant declines in grain area per cell in the frontal cortex between 10 and 30 months of age (Fig. 3B). A frequency distribution of the data for the average grain area per cell for $\epsilon 2$ mRNA in the inner frontal cortex was graphed. The bin size was based on the average size of one grain. The results showed a shift in aged mice to a larger percentage of cells with fewer or no grains per cell when compared with 3-month-old mice (Fig. 3C).

\section{NMDA-displaceable $\left[{ }^{3} \mathrm{H}\right]$ glutamate binding}

There was a significant effect of age, $F_{(2,31)}=9.165, p=0.0007$ and brain region, $F_{(18,558)}=235, p<0.0001$, on NMDAdisplaceable $\left[{ }^{3} \mathrm{H}\right]$ glutamate binding in $\mathrm{C} 57 \mathrm{Bl} / 6$ mice, but no significant interaction between age and brain region, $F_{(36,558)}=$ $0.3109, p=1$. Age-related declines in binding of glutamate to NMDA binding sites were grossly detectable in some brain regions in autoradiographic images (Fig. $4 A-D$ ). Significant decreases in $\left[{ }^{3} \mathrm{H}\right]$ glutamate binding between 3 and 30 months of age were found throughout the cerebral cortex, in the caudate nu-
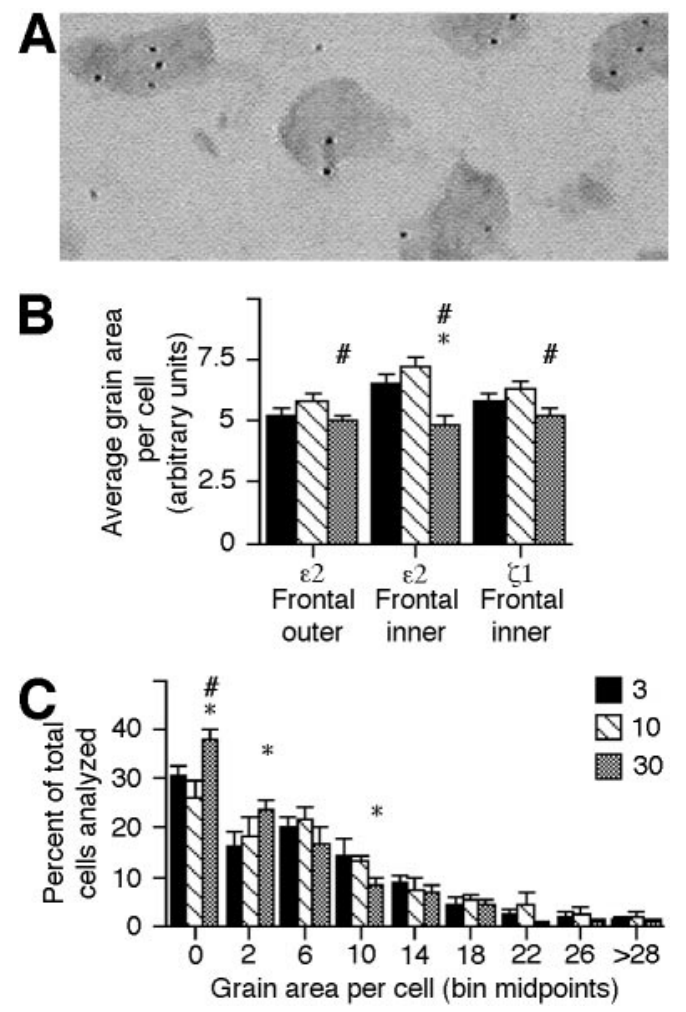

Figure 3. Age-related changes in the amount of mRNA for the NMDA subunits within neurons of the frontal cortex. $A$, Computer image of an emulsion-dipped slide showing cells in layer $\mathrm{V}$ of the frontal cortical region in a 3-month-old mouse. This image was captured by focusing on the silver grains and was then filtered as described in Materials and Methods to enhance the contrast. Black silver grains were primarily located over Giemsa-stained cells. $B$, Graph of the average specific grain area per cell for the mRNA for the $\epsilon 2$ or $\zeta 1$ subunits in the outer (II-III) and/or the inner (IV-VI) layers of the frontal cortex in 3-, 10, and 30-month-old mice. $C$, Frequency graph of the percentage of total cells within each age group that contained the average specific grain area within each bin for the $\epsilon 2$ subunit mRNA in the inner frontal cortex. The bin size was chosen as the average grain size. * indicates $p<0.05$ for difference from 3-month-old mice. \# indicates $p<0.05$ for difference from 10-month-old mice. Legend numbers indicate age in months.

cleus, and in all but one hippocampal region analyzed (Fig. 5A,B). Significant declines in binding were also seen between 3 and 10 months of age in several hippocampal regions (Fig. $5 B$ ).

\section{$\left[{ }^{3} \mathrm{H}\right]$ CPP binding}

There was a significant effect of age, $F_{(2,15)}=5.1907, p=0.02$, and brain region, $F_{(18,270)}=287, p<0.0001$, on $\left[{ }^{3} \mathrm{H}\right] \mathrm{CPP}$ binding to NMDA receptors. There was also a significant interaction between age and brain region, $F_{(36,270)}=2.36, p<0.0001$. Decreased density of binding with increased age was grossly detectable in some brain regions in autoradiographic images (Fig. $4 E-H)$. Significant decreases in $\left[{ }^{3} \mathrm{H}\right] \mathrm{CPP}$ binding were found between 3 and 30 months of age in all but one cortical region and in all hippocampal regions analyzed (Fig. 5C,D). The 30-monthold mice had significantly less binding than 10 month olds in 6 of 10 cortical regions, the dentate gyrus molecular layer, and in stratum oriens of the CA3 region (Fig. 5C,D). Ten-month-old mice had a lower density of binding than 3 month olds in the occipital/temporal cortex and in all hippocampal regions analyzed (Fig. 5C,D). 
Figure 4. NMDA-displaceable $\left[{ }^{3} \mathrm{H}\right]$ glutamate and $\left[{ }^{3} \mathrm{H}\right] \mathrm{CPP}$ binding to the NMDA receptor in different ages of mice. Film autoradiograms for the NMDAdisplaceable $\left[{ }^{3} \mathrm{H}\right]$ glutamate $(A-C)$ and $\left[{ }^{3} \mathrm{H}\right] \mathrm{CPP}(E-G)$ binding in $3(A, E)-, 10(B, F)$-, and $30(C, G)$-month-old mice. $D, H$, Densities (femtomoles per milligram of protein) of binding for different gray levels for $\left[{ }^{3} \mathrm{H}\right]$ glutamate binding in $A-C(D)$ and $\left[{ }^{3} \mathrm{H}\right] \mathrm{CPP}$ binding in $E-G(H)$.
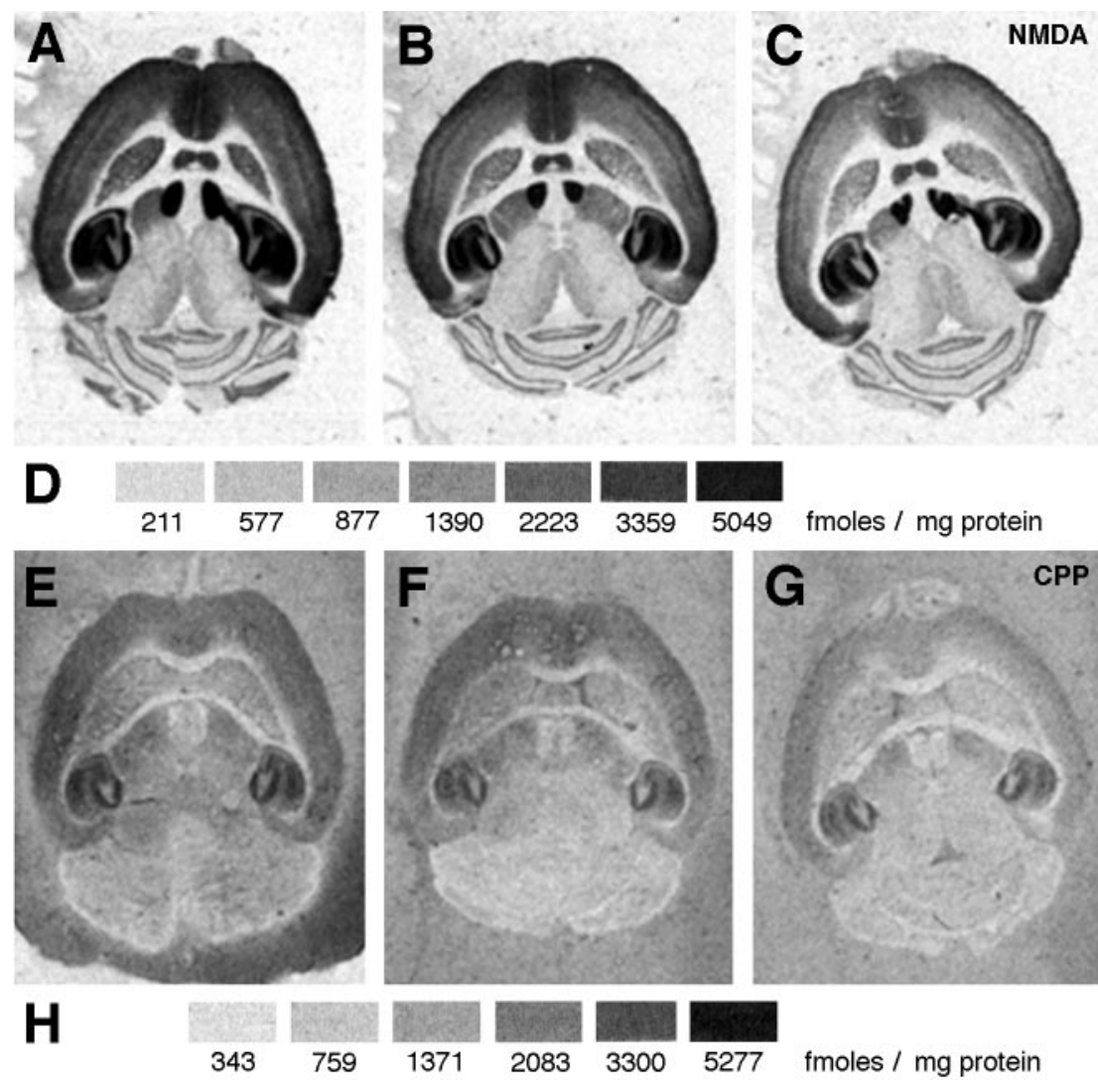

Figure 5. Quantitative comparison of NMDA-displaceable $\left[{ }^{3} \mathrm{H}\right]$ glutamate and $\left[{ }^{3} \mathrm{H}\right] \mathrm{CPP}$ binding within brain regions of different ages of mice. Densities (femtomoles per milligram of protein) of binding for NMDA-displaceable $\left[{ }^{3} \mathrm{H}\right]$ glutamate $(A$, $B)$ and $\left[{ }^{3} \mathrm{H}\right] \mathrm{CPP}(C, D)$ binding in different cortical $(A, C)$ and hippocampal and subcortical $(B, D)$ regions in 3-, 10-, and 30-monthold mice. * indicates $p<0.05$ for difference from 3-month-old mice. \# indicates $p<$ 0.05 for difference from 10 -month-old mice. $A, B, n=12$ for 3 month olds and 11 for 10 and 30 month olds. $C, D, n=6$ for all ages. $\mathrm{Cg}$, Cingulate cortex; $\mathrm{Fr}$, frontal cortex; in, cortical layers V-VI for parietal cortex and IV-VI for all others; out, cortical layers I-III; Par, parietal cortex; mid, cortical layer IV; $O / T$, occipital/temporal; Ent, entorhinal; $l / m$, stratum lacunosum/moleculare; rad, stratum radiatum; or, stratum oriens; $D G$, dentate granule molecular layer; dor, dorsal blade; ven, ventral blade; $C a u$, caudate; $C b$, cerebellum.
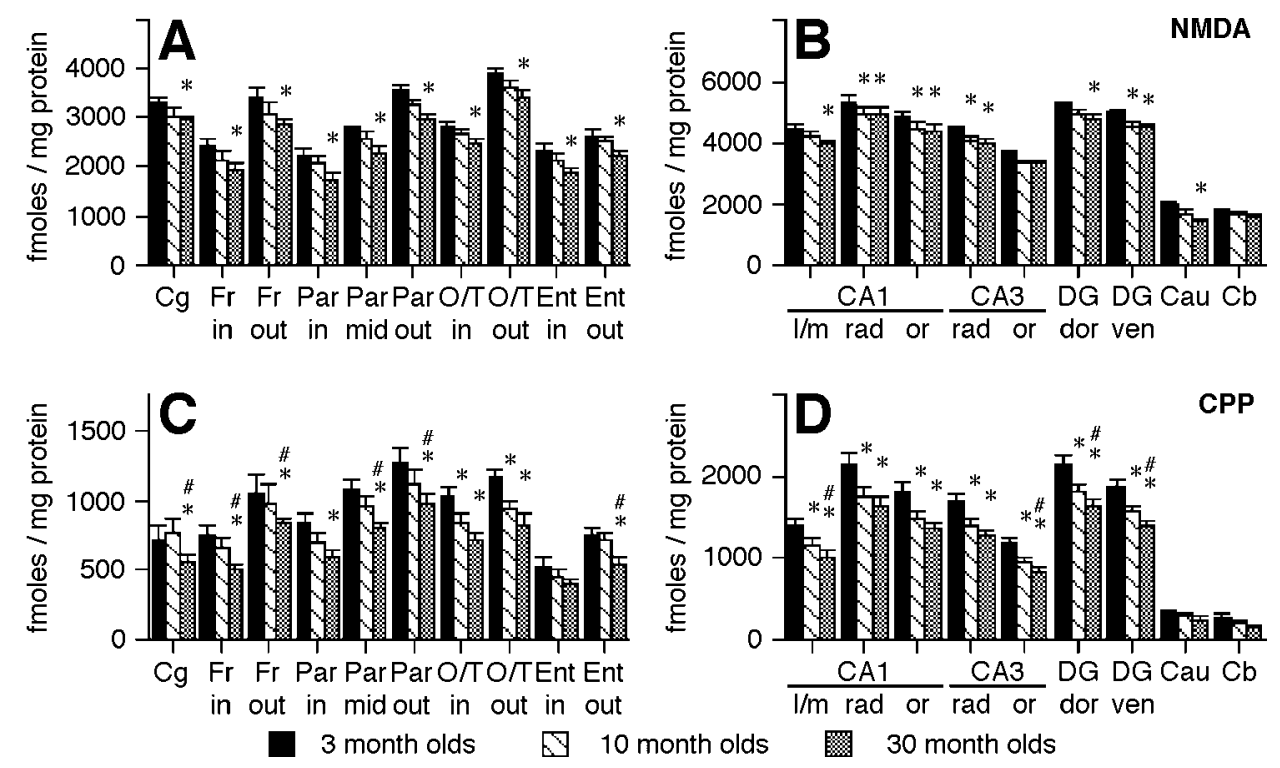

\section{Correlations between NMDA subunit mRNA and binding to the NMDA receptor}

Correlations were performed using age-related changes in binding and mRNA densities across multiple brain regions and were done separately for 10- and 30-month-old mice. Significant correlations were found between age-related changes in NMDAdisplaceable $\left[{ }^{3} \mathrm{H}\right]$ glutamate binding and mRNA densities for the $\epsilon 2$ subunit of the NMDA receptor in the 30-month-old mice (Fig. 6A, Table 1). Changes in $\zeta 1$ mRNA density between 3 and 30 months of age correlated significantly with changes in $\left[{ }^{3} \mathrm{H}\right] \mathrm{CPP}$ binding (Fig. $6 \mathrm{~B}$, Table 1). No other correlations were significant, including the correlation between age-related changes in NMDA-displaceable $\left[{ }^{3} \mathrm{H}\right]$ glutamate and $\left[{ }^{3} \mathrm{H}\right] \mathrm{CPP}$ binding (Fig. 6C, Table 1).

\section{DISCUSSION}

The primary finding of this study was that there was an agerelated decline in the density of mRNA for the $\epsilon 2$ subunit of the NMDA receptor throughout most of the cerebral cortex and in the dentate granule cells in $\mathrm{C} 57 \mathrm{Bl} / 6$ mice. Examination at the cellular level in the inner layers of the frontal regions of the cortex showed a decline in the amount of mRNA for $\epsilon 2$ within the cell 

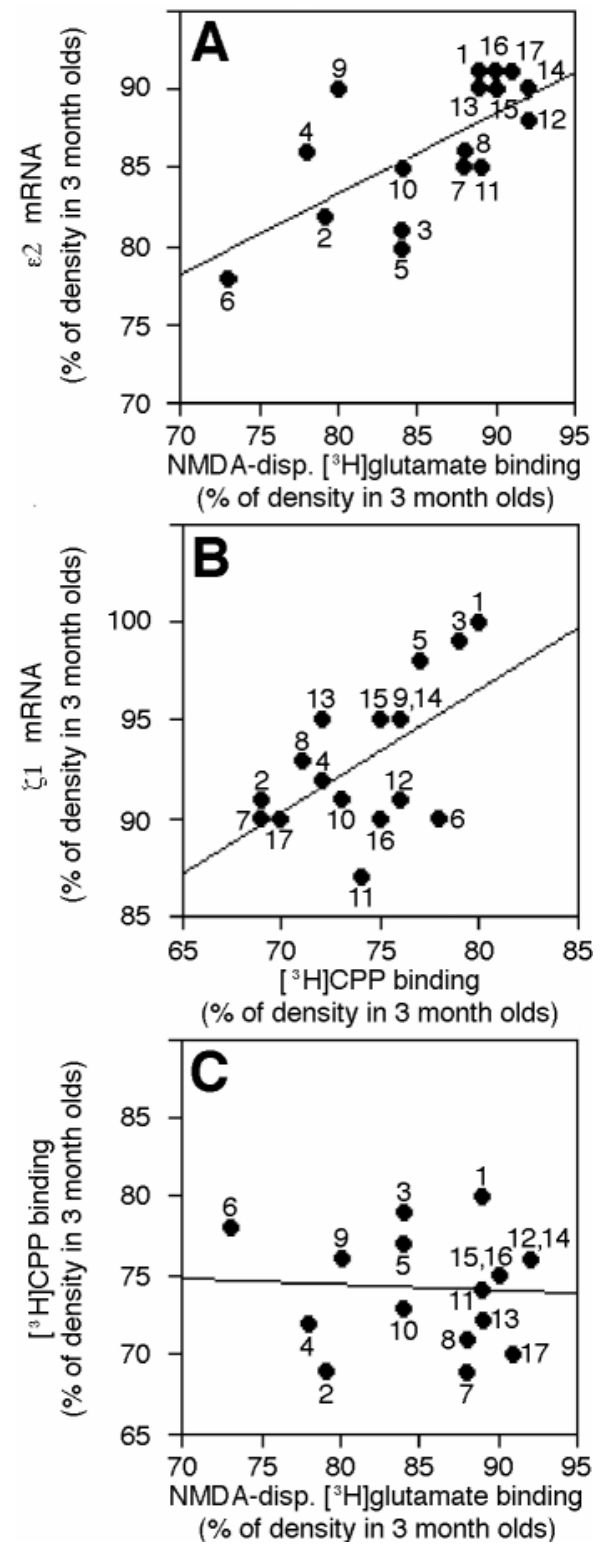

Figure 6. Correlations between age-related changes in mRNA density for NMDA subunits and ligand binding across cortical, hippocampal, and striatal brain regions in 30-month-old mice. $A-C$, Graphs of the relationships between the percentage of densities in 3 month olds remaining in 30 month olds for $\epsilon 2 \mathrm{mRNA}$ and NMDA-displaceable (NMDA-disp.) $\left[{ }^{3} \mathrm{H}\right]$ glutamate binding $(A), \zeta 1 \mathrm{mRNA}$ and $\left[{ }^{3} \mathrm{H}\right] \mathrm{CPP}$ binding $(B)$, and NMDA-displaceable $\left[{ }^{3} \mathrm{H}\right]$ glutamate and $\left[{ }^{3} \mathrm{H}\right] \mathrm{CPP}$ binding $(C)$, obtained by plotting the mean values for different brain regions. Pearson correlation coefficients for each graph are presented in Table 1. 1, Cingulate cortex; 2, frontal inner (IV-VI) cortex; 3, frontal outer (II-III) cortex; 4, parietal inner (V-VI) cortex; 5, parietal outer (II-III) cortex; 6 , caudate nucleus; 7, occipital/temporal inner (IV-VI) cortex; 8 , occipital/temporal outer (II-III) cortex; 9, entorhinal inner (IV-VI) cortex; 10, entorhinal outer (II-III) cortex; 11, ventral blade of dentate molecular layer (binding)/ventral dentate granule cell layer (in situ); 12, dorsal blade of dentate molecular layer (binding)/dorsal dentate granule cell layer (in situ); 13, CA1 stratum lacunosum/moleculare (binding)/CA1 pyramidal cell layer (in situ); 14, CA1 stratum radiatum (binding)/CA1 pyramidal cell layer (in situ); 15, CA1 stratum oriens (binding)/CA1 pyramidal cell layer (in situ); 16, CA3 stratum radiatum (binding)/CA3 pyramidal cell layer (in situ); 17, CA3 stratum oriens (binding)/CA3 pyramidal cell layer (in situ). All outer regions included layers I-III for receptor binding. in 30-month-old mice as compared to 3 month olds. This change during the aging process between 3 and 30 months of age in mRNA expression for the $\epsilon 2$ subunit appeared to be related to the changes seen in agonist, NMDA-displaceable $\left[{ }^{3} \mathrm{H}\right]$ glutamate, binding within the cortex and hippocampus. The $\zeta 1$ subunit also exhibited an overall decline with age that showed a relationship with changes in antagonist, $\left[{ }^{3} \mathrm{H}\right] \mathrm{CPP}$, binding in 30 -month-old mice.

The distributions of the $\zeta 1, \epsilon 1$, and $\epsilon 2$ messages in this study were similar to those reported by Watanabe et al. (1993). During aging, there was an overall significant decrease in the mRNA for the $\zeta 1$ subunit of the NMDA receptor throughout the regions analyzed, however, within brain regions only a few changes were significant. The age-related declines in the message for the $\epsilon 2$ subunit within brain regions, on the other hand, were significant throughout the cortex and in the granule cells of the dentate gyrus. The $\epsilon 1$ mRNA did not show significant changes during aging. The data for the $\epsilon 1$ subunit appeared to suffer from a greater variability between animals than was seen with the other two subunits.

Our preliminary experiments with immunoblots showed declines in the expression of the proteins for both $\zeta 1$ and $\epsilon 2$ subunits in homogenates of whole cortex between 3 and 30 months of age (Kuehl-Kovarik et al., 1998). The protein expression of the $\epsilon 1$ subunit suffered from variability similar to the mRNA analysis (Kuehl-Kovarik et al., 1998). These results suggest that the agerelated changes in mRNA expression for specific subunits of the NMDA receptor in the mouse are accompanied by changes in protein expression. Aged monkeys also show a decline in the expression of the NR1 subunit at the protein level in the distal dendrites of the dentate gyrus (Gazzaley et al., 1996), which is consistent with our mRNA results. Changes during aging in the protein expression of all three subunits have been reported in the hippocampus and striatum of Long-Evans rats (Wang et al., 1996). The NR1 protein is decreased in the hippocampus, and declines in the protein expression of NR1, NR2A, and NR2B are seen in the frontal cortex of patients with Alzheimer's disease (Wang et al., 1997), a disease that is associated with aging and memory deficits (Terry and Katzman, 1983).

The decrease in density of mRNA for the $\epsilon 2$ subunit discovered in the film analysis could have been attributable to a decreased amount of message per cell, a loss of cells with maintenance of message in the remaining cells, or a combination of both. The analysis of silver grains in the inner frontal cortex indicated that at least a portion of the change in message with increasing age was attributable to a decrease in the amount of message per cell. Although this does not rule out a contribution of cell loss, the percentage of decline in amount of message per cell was greater than the change seen in density on film, which argues against cell loss being a major cause of the change. In addition, the new stereological techniques of cell counting indicate that cell loss in the brain during aging is not as prevalent as once was believed (West et al., 1994; Rapp and Gallagher, 1996).

The increased message per cell in the 10-month-old mice as compared to the old mice was not predicted by the film analysis. The emulsion analysis showed significantly less cells with no message and suggested that there was an increased number of cells with higher amounts of grain area per cell in the 10 month olds, as compared to the old mice. More message within a minority of cells might not have influenced the average density of the brain region in film analysis because of the relative lack of silver grains over the neuropil that also contributed to the aver- 
Table 1. Pearson correlation coefficients for age-related changes in mRNA densities for NMDA subunits and densities of ligand binding to NMDA receptors

\begin{tabular}{|c|c|c|c|c|}
\hline & \multicolumn{2}{|l|}{10 -month-old mice } & \multicolumn{2}{|l|}{ 30-month-old mice } \\
\hline & $\begin{array}{l}\text { NMDA-displace- } \\
\text { able }\left[{ }^{3} \mathrm{H}\right] \text { glutamate }\end{array}$ & {$\left[{ }^{3} \mathrm{H}\right] \mathrm{CPP}$} & $\begin{array}{l}\text { NMDA-displace- } \\
\text { able }\left[{ }^{3} \mathrm{H}\right] \text { glutamate }\end{array}$ & {$\left[{ }^{3} \mathrm{H}\right] \mathrm{CPP}$} \\
\hline$\zeta 1 \mathrm{mRNA}$ & 0.28 & -0.18 & 0.05 & $0.58^{*}$ \\
\hline$\varepsilon 1 \mathrm{mRNA}$ & -0.49 & 0.50 & 0.34 & 0.19 \\
\hline$\varepsilon 2$ mRNA & 0.22 & -0.15 & $0.67^{*}$ & -0.09 \\
\hline$\left[{ }^{3} \mathrm{H}\right] \mathrm{CPP}$ & -0.18 & & -0.06 & \\
\hline
\end{tabular}

Means of the percentage of 3-month-old densities remaining in the 10- and 30-month-old mice across 17 individual brain regions were used to examine correlations.

*indicates $p<.05$.

$n=11-12$ for NMDA-displaceable $\left[{ }^{3} \mathrm{H}\right]$ glutamate binding and all subunit mRNAs for 10 -month-old mice.

$n=10-13$ for NMDA-displaceable $\left[{ }^{3} \mathrm{H}\right]$ glutamate binding and all subunit mRNAs for 30-month-old mice. $n=6$ for $\left[{ }^{3} \mathrm{H}\right] \mathrm{CPP}$ for both age groups.

age. These results suggest that the changes in the NMDA receptors that occur during aging are not one continuous process from young adulthood to old age.

The age-related changes in NMDA-displaceable $\left[{ }^{3} \mathrm{H}\right]$ glutamate and $\left[{ }^{3} \mathrm{H}\right] \mathrm{CPP}$ binding to the NMDA receptor were similar to our previous findings, with a few exceptions (Magnusson, 1995). The significant changes between 10 and 30 month olds in this study were seen in less regions for $\left[{ }^{3} \mathrm{H}\right]$ glutamate binding and in more regions for $\left[{ }^{3} \mathrm{H}\right] \mathrm{CPP}$ (Magnusson, 1995). Some variables between the studies include different colonies of mice and different thicknesses of sections (Magnusson, 1995). However, the major finding of greater differences in percentage of decline between $\left[{ }^{3} \mathrm{H}\right] \mathrm{CPP}$ and $\left[{ }^{3} \mathrm{H}\right]$ glutamate binding occurring in the hippocampus as compared to the cortex was consistent between the two studies. This difference in the hippocampus has also been seen in Long-Evans rats (Pelleymounter et al., 1990; Nicolle et al., 1996).

Based on the correlations, it appeared that the changes that occurred in the aged mice in agonist $\left(\left[{ }^{3} \mathrm{H}\right]\right.$ glutamate) binding in many of the cortical and hippocampal regions were related to changes in the mRNA expression of the $\epsilon 2$ subunit of the NMDA receptor. Heteromeric receptors that contain $\zeta 1$ and $\epsilon 2$ subunits exhibit a higher affinity for agonist binding (i.e., twofold and 4.3to 10-fold higher affinities for glutamate and glycine, respectively) than those in which $\epsilon 1$ is paired with the $\zeta 1$ subunit (Kutsuwada et al., 1992; Priestley et al., 1995). Our agonist binding results may be explained by a shift in the population of receptors during aging toward more receptors with a low affinity for agonist. Even though the densities of the mRNA for the $\zeta 1$ subunit did not change to the same degree as $\left[{ }^{3} \mathrm{H}\right] \mathrm{CPP}$ binding, the alterations appeared to be related across brain regions. Because the $\zeta 1$ subunit is believed to be necessary to produce functional receptors (Moriyoshi et al., 1991; Kutsuwada et al., 1992; Meguro et al., 1992; Ishii et al., 1993), it does not seem likely that the greater decline in CPP than glutamate binding could be due to an overall loss of the $\zeta 1$ subunit. The splice variants of the $\zeta 1$ subunit, however, can confer different agonist/antagonist affinities to the receptors (Hollmann et al., 1993). It is possible that changes in one or more of the $\zeta 1$ splice variants may contribute to the differential effect of aging on agonist versus antagonist binding in the hippocampus.

The age-related changes in binding of $\left[{ }^{3} \mathrm{H}\right]$ glutamate to NMDA receptors in the frontal cortical regions and $\left[{ }^{3} \mathrm{H}\right] \mathrm{CPP}$ binding in the hippocampus have been associated with decreased performance in the Morris water maze, a spatial memory task
(Pelleymounter et al., 1990; Magnusson, 1998a). The results of the correlational analyses suggest that changes in the $\epsilon 2$ and $\zeta 1$ subunit may be related to the memory changes as well. Prediction of the consequences of the changes in the $\zeta 1$ subunit will have to await further investigations into the splice variants and protein expression. The age-related changes in the $\epsilon 2$ subunit could have many potential consequences. The atypical, noncompetitive antagonist ifenprodil has a 300-429 fold higher potency for the $\zeta 1 / \epsilon 2$ receptors than the $\zeta 1 / \epsilon 1$ combination (Williams, 1993; Priestley et al., 1995; Gallagher et al., 1996). The $\zeta 1 / \epsilon 2$ receptors are also more sensitive to polyamines (Lynch et al., 1995) and butyrophenones, such as haloperidol, droperidol, and spiperone (Lynch and Gallagher, 1996; Yamakura et al., 1998), than receptors composed of $\zeta 1$ and $\epsilon 1$ subunits. With respect to electrophysiological properties, the $\zeta 1 / \epsilon 2$ receptor has a slower offset time (380 $\mathrm{msec})$ than the $\zeta 1 / \epsilon 1$ receptors $(120 \mathrm{msec}$ ) (Monyer et al., 1992; Seeburg et al., 1994). This means that the sensitivities to drugs and endogenous ligands and the channel open time could all be altered by declines in the expression of the $\epsilon 2$ subunit during aging.

The $\epsilon 2$ subunit, but not the $\zeta 1$ or $\epsilon 1$ subunit, contains the binding site necessary for autophosphorylation-dependent targeting of calcium/calmodulin-dependent kinase II (CaMKII), which in turn is essential for NMDA-dependent LTP (Strack and Colbran, 1998). There also is a relationship between the induction of the expression of the $\epsilon 2$ subunit and the persistence of LTP (Williams et al., 1998). The age-related changes in the $\epsilon 2$ subunit may, at least in part, account for the declines in the expression and persistence of LTP that have been reported in aged animals (Barnes, 1979; Barnes and McNaughton, 1985; Baskys et al., 1990). Additional evidence for the importance of this subunit in learning and memory processes has been provided by transgenic mice in which the $\epsilon 2$ (NR2B) subunit was overexpressed (Tang et al., 1999). These mice show enhanced long-term potentiation and learning abilities.

In conclusion, the differential effects of aging on agonist versus antagonist binding in the hippocampal region appear to be related to changes in two different subunits of the NMDA receptor. A determination of why certain subunits are more influenced by the aging process than others will be necessary before it can be determined whether effective interventions can be designed to prevent this change in the NMDA receptor and potentially reduce the memory declines associated with aging. 


\section{REFERENCES}

Albert MS, Funkenstein HH (1992) The effects of age: normal variation and its relation to disease. In: Diseases of the nervous system: clinical neurobiology (Asbury AK, McKhann GM, McDonald WI, eds), pp 598-611. Philadelphia: Saunders.

Alessandri B, Battig K, Welzl H (1989) Effects of ketamine on tunnel maze and water maze performance in the rat. Behav Neural Biol $52: 194-212$.

Artola A, Singer W (1994) NMDA receptors and developmental plasticity in visual neocortex. In: The NMDA receptor (Collingridge GL, Watkins JC, eds), pp 313-339. Oxford: Oxford UP.

Barnes CA (1979) Memory deficits associated with senescence: a neurophysiological and behavioral study in the rat. J Comp Physiol Psychol 93:74-104.

Barnes CA (1988) Aging and the physiology of spatial memory. Neurobiol Aging 9:563-568.

Barnes CA, McNaughton BL (1985) An age comparison of the rates of acquisition and forgetting of spatial information in relation to long-term enhancement of hippocampal synapses. Behav Neurosci 99:1040-1048.

Bashir Z, Alford S, Davies S, Randall A, Collingridge G (1991) Longterm potentiation of NMDA receptor-mediated synaptic transmission in the hippocampus. Nature 349:156-158.

Baskys A, Reynolds J, Carlen P (1990) NMDA depolarizations and long-term potentiation are reduced in the aged rat neocortex. Brain Res 530:142-146.

Cotman CW, Bridges RJ, Taube JS, Clark AS, Geddes JW, Monaghan DT (1989) The role of the NMDA receptor in central nervous system plasticity and pathology. J NIH Res 1:65-74.

Deupree DL, Bradley J, Turner DA (1993) Age-related alterations in potentiation in the CA1 region in F344 rats. Neurobiol Aging 14:249-258.

Gage F, Dunnett S, Bjorklund A (1984) Spatial learning and motor deficits in aged rats. Neurobiol Aging 5:43-48.

Gallagher M, Nicolle MM (1993) Animal models of normal aging: relationship between cognitive decline and markers in hippocampal circuitry. Behav Brain Res 57:155-162.

Gallagher M, Rapp PR (1997) The use of animal models to study the effects of aging on cognition. Annu Rev Psychol 48:339-370.

Gallagher MJ, Huang H, Pritchett DB, Lynch DR (1996) Interactions between ifenprodil and the NR2B subunit of the $N$-methyl-D-aspartate receptor. J Biol Chem 271:9603-9611.

Gazzaley AH, Siegel SJ, Kordower JH, Mufson EJ, Morrison JH (1996) Circuit-specific alterations of $N$-methyl-D-aspartate receptor subunit 1 in the dentate gyrus of aged monkeys. Proc Natl Acad Sci USA 93:3121-3125.

Gonzales RA, Brown LM, Jones TW, Trent RD, Westbrook SL, Leslie SW (1991) $N$-methyl-D-aspartate mediated responses decrease with age in Fischer 344 rat brain. Neurobiol Aging 12:219-225.

Harris EW, Ganong A, Cotman CW (1984) Long-term potentiation in the hippocampus involves activation in $N$-methyl-D-aspartate receptors. Brain Res 323:132-137.

Head E, Mehta R, Hartley J, Kameka M, Cummings BJ, Cotman CW, Ruehl WW, Milgram NW (1995) Spatial learning and memory as a function of age in the dog. Behav Neurosci 109:851-858.

Heale V, Harley C (1990) MK801 and AP5 impair acquisition, but not retention, of the Morris milk maze. Pharmacol Biochem Behav 36:145-149.

Hollmann M, Boulter J, Maron C, Beasley L, Sullivan J, Pecht G, Heinemann S (1993) Zinc potentiates agonist-induced currents at certain splice variants of the NMDA receptor. Neuron 10:943-954.

Ikeda K, Nagasawa M, Mori H, Araki K, Sakimura K, Watanabe M, Inoue Y, Mishina M (1992) Cloning and expression of the $\epsilon 4$ subunit of the NMDA receptor channel. FEBS Lett 313:34-38.

Ishii T, Moriyoshi K, Sugihara H, Sakurada K, Kadotani H, Yokoi M, Akazawa C, Shigemoto R, Mizuno N, Masu M, Nakanishi S (1993) Molecular characterization of the family of the $N$-methyl-D-aspartate receptor subunits. J Biol Chem 268:2836-2843.

Kito S, Miyoshi R, Nomoto T (1990) Influence of age on NMDA receptor complex in rat brain studied in in vitro autoradiography. J Histochem Cytochem 38:1725-1731.

Kuehl-Kovarik MC, Partin KM, Sammonds GE, Magnusson KR (1998) Protein and mRNA expression of different NMDA receptor subunits exhibit decline during aging. Soc Neurosci Abstr 24:2180.

Kutsuwada T, Kashiwabuchi N, Mori H, Sakimura K, Kushiya E, Araki
K, Meguro H, Masaki H, Kumanishi T, Arakawa M, Mishina M (1992) Molecular diversity of the NMDA receptor channel. Nature 358:36-41.

Lynch DR, Gallagher MJ (1996) Inhibition of $N$-methyl-D-aspartate receptors by haloperidol. Development and pharmacological characterization in native and recombinant receptors. J Pharmacol Exp Ther 279:154-161.

Lynch DR, Lawrence JJ, Lenz S, Anegawa NJ, Dichter M, Pritchett DB (1995) Pharmacological characterization of heterodimeric NMDA receptors composed of NR1a and 2B subunits: differences with receptors formed from NR1a and 2A. J Neurochem 64:1462-1468.

Magnusson KR (1995) Differential effects of aging on binding sites of the activated NMDA receptor complex in mice. Mech Ageing Dev 84:227-243

Magnusson KR (1998a) The aging of glutamate receptors: Correlations between receptor binding and spatial memory performance in C57B1 mice. Mech Ageing Dev 104:227-248.

Magnusson KR (1998b) The aging of the NMDA receptor complex. Front Biosci 3:e 70-80.

Marks MJ, Pauly JR, Gross SD, Deneris ES, Hermans-Borgmeyer I, Heinemann SF, Collins AC (1992) Nicotine binding and nicotinic receptor subunit RNA after chronic nicotine treatment. J Neurosci 12:2765-2784.

Meguro H, Mori H, Araki K, Kushiya E, Kutsuwada T, Yamazaki M, Kumnainshi T, Arakawa M, Sakimura K, Mishina M (1992) Functional characterization of a heteromeric NMDA receptor channel expressed from cloned cDNAs. Nature 357:70-74.

Mondadori C, Weiskrantz L, Buerki H, Petschke F, Fagg GE (1989) NMDA receptor antagonists can enhance or impair learning performance in animals. Exp Brain Res 75:449-456.

Monyer H, Sprengel R, Schoepfer R, Herb A, Higuchi M, Lomeli H, Burnashev N, Sakmann B, Seeburg PH (1992) Heteromeric NMDA receptors: Molecular and functional distinction of subtypes. Science 256:1217-1221.

Moriyoshi K, Masu M, Ishii T, Shigemoto R, Mizuno N, Nakanishi S (1991) Molecular cloning and characterization of the rat NMDA receptor. Nature 354:31-37.

Morris RGM, Davis M (1994) The role of NMDA receptors in learning and memory. In: The NMDA receptor (Collingridge GL, Watkins JC, eds), pp 340-375. Oxford: Oxford UP.

Morris RGM, Anderson E, Lynch GS, Baudry M (1986) Selective impairment of learning and blockade of long-term potentiation by an $N$-methyl-D-aspartate receptor antagonist, AP5. Nature 319:774-776.

Nakanishi S (1992) Molecular diversity of glutamate receptors and implications for brain function. Science 258:597-603.

Nicolle MM, Bizon JL, Gallagher M (1996) In vitro autoradiography of ionotropic glutamate receptors in hippocampus and striatum of aged Long-Evans rats: relationship to spatial learning. Neuroscience 74:741-756.

Pelleymounter MA, Beatty G, Gallagher M (1990) Hippocampal 3HCPP binding and spatial learning deficits in aged rats. Psychobiology 18:298-304.

Piggott MA, Perry EK, Perry RH, Court JA (1992) [ $\left.{ }^{3} \mathrm{H}\right] \mathrm{MK}-801$ binding to the NMDA receptor complex, and its modulation in human frontal cortex during development and aging. Brain Res 588:277-286.

Pittaluga A, Fedele E, Risiglione C, Raiteri M (1993) Age-related decrease of the NMDA receptor-mediated noradrenaline release in rat hippocampus and partial restoration by D-cycloserine. Eur J Pharmacol 231:129-134.

Priestley T, Laughton P, Myers J, le Bourdelles B, Kerby J, Whiting PJ (1995) Pharmacological properties of recombinant human $N$-methyl-Daspartate receptors comprising NR1a/NR2A and NR1a/NR2B subunit assemblies expressed in permanently transfected mouse fibroblast cells. Mol Pharmacol 48:841-848.

Rapp P, Rosenberg R, Gallagher M (1987) An evaluation of spatial information processing in aged rats. Behav Neurosci 101:3-12.

Rapp PR, Gallagher M (1996) Preserved neuron number in the hippocampus of aged rats with spatial learning deficits. Proc Natl Acad Sci USA 93:9926-9930.

Seeburg PH, Monyer H, Sprengel R, Burnashev N (1994) Molecular biology of NMDA receptors. In: The NMDA receptor (Collingridge GL, Watkins JC, eds), pp 147-157. Oxford: Oxford UP.

Smolen AJ, Beaston-Wimmer P (1990) Quantitative analysis of in situ hybridization using image analysis. In: In Situ hybridization histochemistry (Chesselet M-F, eds), pp 175-188. Boston: CRC.

Strack S, Colbran RJ (1998) Autophosphorylation-dependent targeting 
of calcium/calmodulin-dependent protein kinase II by the NR2B subunit of the $N$-methyl-D-aspartate receptor. J Biol Chem 273:20689-20692.

Tamaru M, Yoneda Y, Ogita K, Shimizu J, Nagata Y (1991) Age-related decreases of the $N$-methyl-D-aspartate receptor complex in the rat cerebral cortex and hippocampus. Brain Res 542:83-90.

Tang Y-P, Shimizu E, Dube GR, Rampon C, Kerchner GA, Zhuo M, Liu G, Tsien JZ (1999) Genetic enhancement of learning and memory in mice. Nature 401:63-69.

Terry RD, Katzman R (1983) Senile dementia of the Alzheimer's type. Ann Neurol 14:497-506.

Wang Y-H, Yasuda RP, Mash DC, Wolfe BB (1997) Both NMDA and AMPA receptor subunits are altered in Alzheimer's disease. Soc Neurosci Abstr 23:1895.

Wang YH, Luo JH, Yasuda RP, Gallagher M, Kellar KJ, Wolfe BB (1996) Age-related changes in NMDA receptor subunits, NR1, NR2A, and NR2B in rat striatum and hippocampus. Soc Neurosci Abstr 22:1892.

Watanabe M, Inoue Y, Sakimura K, Mishina M (1992) Developmentalchanges in distribution of NMDA receptor channel subunit mRNAs. NeuroReport 3:1138-1140.

Watanabe M, Inoue Y, Sakimura K, Mishina M (1993) Distinct distri- butions of five $N$-methyl-D-aspartate receptor channel subunit mRNAs in the forebrain. J Comp Neurol 338:377-390.

Wenk GL, Walker LC, Price DL, Cork LC (1991) Loss of NMDA, but not GABA-A, binding in the brains of aged rats and monkeys. Neurobiol Aging 12:93-98.

West MJ, Coleman PD, Flood DG, Troncosco JC (1994) Differences in the pattern of hippocampal neuronal loss in normal ageing and Alzheimer's disease. Lancet 344:769-772.

Williams JM, Mason-Parker SE, Abraham WC, Tate WP (1998) Biphasic changes in the levels of $N$-methyl-D-aspartate- 2 subunits correlate with the induction and persistence of long-term potentiation. Mol Brain Res 60:21-27.

Williams K (1993) Ifenprodil discriminates subtypes of the $N$-methyl-Daspartate receptor: selectivity and mechanisms at recombinant heteromeric receptors. Mol Pharmacol 44:851-859.

Yamakura T, Sakimura K, Mishina M, Shimoji K (1998) Sensitivity of the $N$-methyl-D-aspartate receptor channel to butyrophenones is dependent on the $\epsilon 2$ subunit. Neuropharmacology 37:709-717.

Yamazaki M, Mori H, Araki K, Mori KJ, Mishina M (1992) Cloning, expression and modulation of a mouse NMDA receptor subunit. FEBS Lett 300:39-45. 